\title{
Academic Relationships and Resources: Assessing the Impact on Quality of Education
}

\author{
M.Pragnashree $^{1}$, M.Vidyasagar ${ }^{2}$ and T. Narayan Reddy ${ }^{3}$ \\ ${ }^{1}$ Research Scholar, ${ }^{3}$ Assistant Professor, Department of Management Science, JNTUA, Anantapur, Andhra Pradesh, India \\ ${ }^{2}$ Associate Professor, Department of Management Studies, SVCET (A) Chittoor, Andhra Pradesh, India \\ E-mail: pragnashrimunigoti@gmail.com
}

\begin{abstract}
The study is an empirical examination of how the academic relationship between Faculty and student, student's access to resources affect the quality of education in higher education institutions across Andhra Pradesh, India. Data was collected among 400 students across Higher Education institutions in Andhra Pradesh using random sampling technique. Dimensions of SERVQUAL model (ParasurRaman, 1985), namely Responsiveness, Cooperation, Assurance, Empathy, Tangibles (Access to resources) were used in the questionnaire. Cross tabulation in SPSS and Pearson correlation were employed as analytical methods. The findings of the study suggest that the student faculty relationship have a significant impact on quality of education and academic resources are significant attributes that impact the student's learning which results in better quality of education.
\end{abstract}

Keywords: SERVQUAL, Academic Relationship, Higher Education, quality education, Academic Resources.

\section{INTRODUCTION}

The program of higher education in India is undergoing drastic change as a number of private colleges and universities are emerging. Universities are continuously bringing in improvements to maximize performance and productivity of all internal processes and communications with main stakeholders to ensure good quality. Education in society is fast changing (Mircea \& Andreescu, 2010). There are numerous explanations about education and various factors identified in defining the parameters for education and its quality. Socrates explains that Education is to bring out the ideas of universal validity which are latent in every human being. However, Aristotle defines that Education is the creation of a sound mind in a sound body. All the definitions indicate to the invincible fact that education plays an important role in development of a nation's Economy (Brennan \& Teichler, 2008). Students being an inseparable part of this process, Students' credentials and opinions contribute significantly in defining the quality of education (Akareem \& Hossain 2012). There have been studies as early as 1960 s to define quality in education. All these studies have tried to define parameters with regards to quality in education and its impact. It is observed that Higher education is facing high demand to improve value in its activities (Heck \& Johnsrud, 2000). Thus, it is important to address the needs of all stakeholders of education more than ever now. Students being major stakeholders play a paramount role in the quality of education. Students have better information and insights about the quality, experiences, amenities and ambience of an education institution owing to social media presence, globalization and information technology. This new phenomenon changes the fundamental objective of education institutions of not just providing education but also to address various other trending needs and the organizations needs to come up with a system of planned selection of technologies to fulfil these trending needs. To implement these changes there is a need to establish a strong bonding between student and faculty. In the case of educational services, quality of academic relationship and academic resources are vital elements to students' evaluations. Service quality is a method to judge overall performance of a service. Higher education institutions, of late, are concerned about service quality to improve their standards. Service quality is a critical analysis of customer perceptions. Here, students judge the quality of services based on their perceptions of the outcome quality, interaction quality, and physical environment quality. The dimensions of service quality that have been identified and used are based on the pioneering research of Parasuraman, Valarie Zeithaml and Leonard Berry.

\section{LITERATURE REVIEW}

Though there is a vast body of work about quality, quality is still a relative term. And one immediate sure shot byproduct of quality is satisfaction. According to Zeithaml (1988), satisfaction is the result of consistent output of the administrative and educational structures in the higher education institutions. Zeithaml argues that the students are driven to finish their studies when an institution offers an environment where in learning is easier and that includes sufficient educational infrastructure and utility is generated as per academic criteria which foster academic growth.

Wachtel, (1998) maintains that students' rate their subject teacher's performance and their pedagogy of teaching as vital indicators in their educational development and successful completion of their studies because higher the intellectual ability of the instructor the better will be the students' evaluation (Edstrom, 2008) and, consequently, the more will be the reliability of the teaching staff. Crawford and Shutler, (1999) examined in their study that service quality is one of the key elements for a higher education institute to achieve success in a competitive market. There 
are numerous factors identified all through the years of study by various researchers that influence service quality in higher education. Astin \& Chang (1995) emphasize that students at HEIs run into challenges to faculty access.

Astin et al (1993) found in their study that faculty have a lasting impact on students and students who have a fulfilling experience with faculty, institution, curriculum have a greater chance to develop academically. Thus management and staff are required to be committed to continuous quality improvement in their services (academic and administration). Navarro et al. (2005) mentioned in their study that students evaluate the quality of organization based on tangibility (teachers), reliability and responsiveness (methods of teaching) and management of the institution and these factors have first hand impact on the magnitude of students' opinions.

Another study by Spooreen et al. (2007) posited that the culture in organization, the intellectual competence of teachers, professional development, transparency in students' evaluation, are the important factors that help develop students. Mahiah et al. (2006) in their study suggested that tangibility, assurance, empathy, and responsiveness can potentially improve customer satisfaction towards services rendered by human resource department. Hence, it can be inferred that service quality in an education institution is predominantly dependent on diverse factors and academic relationship among faculty and student and availability of resources is among them.

\section{OBJECTIVES OF THE STUDY}

The study has two objectives (i) to examine if academic relationship of faculty and students leads to quality of education. (ii) to examine if access to academic resources effect the learning levels of students. The study extracted attributes of qualitative relationship in academic settings from SERVQUAL model namely Cooperation, Responsiveness, Tangibles (access to academic resources), Assurance and Empathy of faculty towards students that results in Quality of Education.

\section{SIGNIFICANCE OF STUDY}

The study aims to determine the extent to which the faculty student relationship influences quality of education in institutions. It seeks to understand the perspective and opinions of students that shall play an important role for policy making and performance of HEIs.

\section{METHODOLOGY}

The present study used a close ended questionnaire consisting 4 sections. Section A contain questions about demographics (gender, age group, course of study, type of institution), section B consisted questions about Cooperation and Responsiveness of faculty towards students. Section C consist questions about Assurance and
Empathy. Section D has questions about Academic resources and their accessibility to students and role of students in quality of education.

A total of 400 questionnaires were distributed across the state using Google forms, out of which 125 responses were usable. The sample constitutes $53.6 \%$ female respondents and $41.6 \%$ of the respondents fall in the age group of 22 and above. The sample was collected from colleges which were categorized as Affiliated, Autonomous, University and others. $48.8 \%$ of the respondents belong to affiliated colleges, $35.2 \%$ respondents enrolled in Engineering courses and $47.2 \%$ of the respondents belong to Management courses. The survey was conducted from 2019 to 2020 .

All the respondents' opinions were recorded on a model and measured by using a 5-point Likert scale.

Table I represents the demographic profile of the respondents

TABLE I PROFILE OF THE RESPONDENTS

\begin{tabular}{|c|l|c|c|}
\hline Characteristics & \multicolumn{1}{|c|}{ Groups } & Frequency & Percentage \\
\hline \multirow{3}{*}{ Gender } & Male & 58 & 46.4 \\
\cline { 2 - 4 } & Female & 67 & 53.6 \\
\hline \multirow{3}{*}{ Age } & $18-20$ years & 31 & 24.8 \\
\cline { 2 - 4 } & $21-22$ years & 42 & 33.6 \\
\cline { 2 - 4 } & Above 22 years & 52 & 41.6 \\
\hline \multirow{4}{*}{ College Type } & Affiliated College & 61 & 48.8 \\
\cline { 2 - 4 } & Autonomous & 32 & 25.6 \\
\cline { 2 - 4 } & University & 28 & 22.4 \\
\cline { 2 - 4 } & Others & 4 & 3.2 \\
\hline \multirow{3}{*}{ Course } & Engineering & 44 & 35.2 \\
\cline { 2 - 4 } & Management & 59 & 47.2 \\
\cline { 2 - 4 } & Others & 22 & 17.6 \\
\hline \multicolumn{2}{|c|}{ Total } & 125 & 100.0 \\
\hline
\end{tabular}

\section{CONCEPTUAL FRAMEWORK OF STUDY}

To study the impact of academic relationship and accessibility of resources on quality of education, a model was developed. The figure below depicts the conceptual framework to understand the relationship between academic relationship of student-faculty, Access to resources and to the extent to which they affect the quality of education in HEIs.

Attributes of SERVQUAL (Parasuraman \& Zeithaml V. A., 1985) Cooperation, Responsiveness, Assurance and Empathy were used. Tangibles represent academic resources in education institutions. Hence Tangibles are deemed as Academic resources for the present study. 


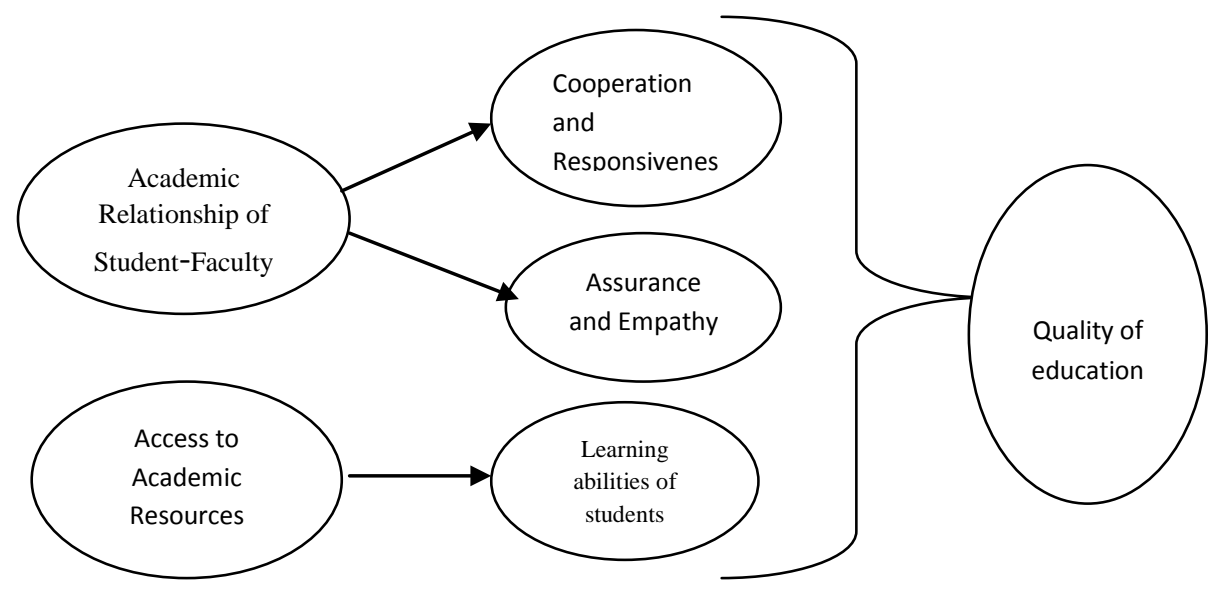

Fig.1 Academic Resources in Education Institutions

\section{HYPOTHESES OF THE STUDY}

H1: Cooperation \& Responsiveness of faculty towards students results in improved quality of education.

H2: Access to tangibles (academic resources) of Students leads to significant learning among students.
H3: Empathy \& Assurance of faculty impacts performance of students.

\section{HYPOTHESES TESTING AND DISCUSSION}

H1: Cooperation \& Responsiveness of faculty towards students results in improved quality of education

TABLE II COOPERATION AND RESPONSIVENESS ( $\mathrm{N}=125)$

\begin{tabular}{|c|c|c|c|c|c|c|c|c|}
\hline \multirow{2}{*}{$\begin{array}{l}\text { Sl. } \\
\text { No. }\end{array}$} & \multirow{2}{*}{ Cooperation and responsiveness } & \multicolumn{5}{|c|}{$<<$ Level of Agreement $>>$} & \multirow{2}{*}{ Mean } & \multirow{2}{*}{ S.D. } \\
\hline & & 1 & 2 & 3 & 4 & 5 & & \\
\hline 1 & $\begin{array}{l}\text { Faculty have a Personal level connect with } \\
\text { student in our institution }\end{array}$ & 2(1.6) & $9(7.2)$ & $25(20.0)$ & 69(55.2) & $20(16.0)$ & 3.77 & 0.863 \\
\hline 2 & $\begin{array}{l}\text { Faculty is mostly available for guidance and } \\
\text { inquiry for a student in our institution }\end{array}$ & - & $7(5.6)$ & $11(8.8)$ & $75(60.0)$ & $32(25.6)$ & 4.06 & 0.755 \\
\hline 3 & $\begin{array}{l}\text { Faculty help students who have difficulty to } \\
\text { cope up with learning }\end{array}$ & $1(0.8)$ & $10(8.0)$ & $27(21.6)$ & 62(49.6) & $25(20.0)$ & 3.80 & .8080 \\
\hline 4 & $\begin{array}{l}\text { Faculty pay individual attention to a student } \\
\text { when necessary }\end{array}$ & - & 12(9.6) & $37(29.6)$ & $56(44.8)$ & 20(16.0) & 3.67 & $\begin{array}{c}00.85 \\
9\end{array}$ \\
\hline 5 & $\begin{array}{l}\text { Faculty feel a personal obligation to fulfill the } \\
\text { student's academic needs }\end{array}$ & $3(2.4)$ & $11(8.8)$ & $32(25.6)$ & 63(50.4) & $16(12.8)$ & 3.62 & 0.904 \\
\hline 6 & $\begin{array}{l}\text { Faculty are held responsible for pass } \\
\text { percentage of a subject they handle }\end{array}$ & $2(1.6)$ & 12(9.6) & $27(21.6)$ & $65(52.0)$ & 19(15.2) & 3.70 & 0.900 \\
\hline 7 & $\begin{array}{l}\text { Faculty are available over phone/mail for any } \\
\text { assistance of the student }\end{array}$ & $1(0.8)$ & $13(10.4)$ & $16(12.8)$ & $64(51.2)$ & $31(24.8)$ & 3.89 & 0.926 \\
\hline 8 & $\begin{array}{l}\text { Faculty are consistently courteous with the } \\
\text { student in our institution }\end{array}$ & $1(0.8)$ & 12(9.6) & $24(19.2)$ & $69(55.2)$ & $19(15.2)$ & 3.74 & 0.860 \\
\hline 9 & $\begin{array}{l}\text { Faculty are prompt enough to solve issues of } \\
\text { students in our institution }\end{array}$ & $1(0.8)$ & $7(5.6)$ & $34(27.2)$ & $65(52.0)$ & $18(14.4)$ & 3.74 & 0.805 \\
\hline \multicolumn{7}{|c|}{ Overall Cooperation and responsiveness Score } & 3.78 & 0.566 \\
\hline
\end{tabular}

Note: '-'denotes 'no response', Anchors: 1-Strongly disagree, 2-Disagree, 3-Neutral, 4-Agree \& 5-Strongly agree

From the above table 2, the overall mean and standard deviation of Overall Cooperation and responsiveness was observed to be 3.78 and 0.566 . Further it was observed that, students were of opinion that faculty were available to guide with a mean score of 4.06 followed by faculty available over phone or mail to assist them with a mean score of 3.89.This suggests that, students were of opinion that responsiveness and cooperation is significant in student faculty relationship.

\footnotetext{
**. Correlation is significant at the 0.01 level (2-tailed).
}

In order to test the hypothesis Cooperation \& Responsiveness of faculty towards students results in improved quality of education a correlation test was conducted and the results are as follows

\section{TABLE III CORRELATIONS}

\begin{tabular}{|c|c|c|}
\hline \multicolumn{2}{|c|}{} & Quality of education \\
\hline Cooperation \& & Pears on Correlation & $0.517^{* *}$ \\
\cline { 2 - 3 } Responsiveness & Sig. (2-tailed) & 0.000 \\
\cline { 2 - 3 } $\begin{array}{c}\text { of faculty } \\
\text { towards students }\end{array}$ & $\mathrm{N}$ & 125 \\
\hline
\end{tabular}


From the above table III it is evident that there is a correlation between Cooperation \& Responsiveness of faculty towards students and the quality of education, although there is a correlation between the two factors, the relation stands positive but not too strong in nature. Thus $\mathrm{H} 1$ is accepted at 0.01 level.
H2: Access to tangibles (academic resources) of Students leads to significant learning among students.

TABLE IV ACADEMIC RESOURCES (N=125)

\begin{tabular}{|c|c|c|c|c|c|c|c|c|}
\hline \multirow{2}{*}{$\begin{array}{l}\text { Sl. } \\
\text { No. }\end{array}$} & \multirow{2}{*}{ Academic Resources } & \multicolumn{5}{|c|}{$<<$ Level of Agreement $>>$} & \multirow{2}{*}{$\begin{array}{c}\text { Mea } \\
\mathrm{n}\end{array}$} & \multirow{2}{*}{ S.D. } \\
\hline & & 1 & 2 & 3 & 4 & 5 & & \\
\hline 1 & $\begin{array}{l}\text { The learning environment is well-adapted to } \\
\text { effective teaching and learning and facilitates a } \\
\text { wide range of teaching approaches }\end{array}$ & - & $7(1.8)$ & 49(12.8) & 277(72.3) & $50(13.1)$ & 3.97 & 0.576 \\
\hline 2 & $\begin{array}{l}\text { The Physical facilities in institution are visually } \\
\text { appealing }\end{array}$ & - & $8(2.1)$ & $84(21.9)$ & 241(62.9) & $50(13.1)$ & 3.87 & 0.646 \\
\hline 3 & $\begin{array}{l}\text { Well-equipped laboratories /classrooms with } \\
\text { modern facilities are available in institution }\end{array}$ & - & $5(1.3)$ & $88(23.0)$ & 232(60.6) & $58(15.1)$ & 3.90 & 0.651 \\
\hline 4 & $\begin{array}{l}\text { Appearance of the physical facilities are } \\
\text { consistent with the type of service industry }\end{array}$ & $1(0.3)$ & $10(2.6)$ & $98(25.6)$ & $228(59.5)$ & $46(12.0)$ & 3.80 & 0.683 \\
\hline 5 & $\begin{array}{l}\text { Comprehensive learning resources are available } \\
\text { in our institution }\end{array}$ & $2(0.5)$ & 15(3.9) & $83(21.7)$ & 235(61.4) & $48(12.5)$ & 3.81 & 0.716 \\
\hline 6 & $\begin{array}{l}\text { Experimentation and innovation in teaching } \\
\text { practices are encouraged and rewarded in our } \\
\text { institution }\end{array}$ & $1(0.3)$ & $17(4.4)$ & 81(21.1) & 243(63.4) & 41(10.7) & 3.80 & 0.693 \\
\hline 7 & $\begin{array}{l}\text { Knowledge-sharing platforms and other } \\
\text { instruments are available to support diffusion } \\
\text { of innovative practices. }\end{array}$ & - & $17(4.4)$ & 75(19.6) & $249(65.0)$ & $42(11.0)$ & 3.83 & 0.674 \\
\hline 8 & $\begin{array}{l}\text { Quality programs are designed to prepare the } \\
\text { students for industry needs }\end{array}$ & $1(0.3)$ & 14(3.7) & $87(22.7)$ & 231(60.3) & $50(13.1)$ & 3.82 & 0.705 \\
\hline 9 & $\begin{array}{l}\text { Students have access to library, } \\
\text { magazines/journals, Wi-Fi /Internet, digital } \\
\text { books without hassle }\end{array}$ & - & 13(3.4) & 74(19.3) & 231(60.3) & $65(17.0)$ & 3.91 & 0.701 \\
\hline \multicolumn{7}{|c|}{ Overall Academic Resources Score } & 3.86 & 0.397 \\
\hline
\end{tabular}

Note: '-‘denotes 'no response’ Anchors: 1-Strongly disagree, 2-Disagree,

3-Neutral, 4-Agree \& 5-Strongly agree

From the above table IV, the overall mean and standard deviation of Academic resources was observed to be 3.86 and 0.397 .

Further it was observed that, students were of opinion that the learning environment is well-adapted to effective teaching and learning and also facilitates a wide range of teaching approaches with a highest mean score of 3.97 followed by access to library, magazines/journals, Wi-Fi /Internet, digital books without hassle which becomes a part of academic resources with a mean score of 3.91.

This suggests that, students were of opinion that academic resources were of significant attributes that impact the student's learning which results in quality of education.

In order to test the hypothesis Access to tangibles (academic resources) of Students leads to significant learning among students a correlation test was conducted and the results was mentioned below.
TABLE V CORRELATIONS

\begin{tabular}{|l|l|c|}
\hline \multicolumn{2}{|c|}{} & Student Learning \\
\hline \multirow{3}{*}{$\begin{array}{l}\text { Academic } \\
\text { Resources }\end{array}$} & Pearson Correlation & $0.610^{* *}$ \\
\cline { 2 - 3 } & Sig. (2-tailed) & 0.000 \\
\cline { 2 - 3 } & $\mathrm{N}$ & 125 \\
\hline
\end{tabular}

**. Correlation is significant at the 0.01 level (2-tailed).

From the above table $\mathrm{V}$ it is evident that there is a correlation between Access to tangibles (academic resources) of Students leads to significant learning among students, also it is evident that there is a correlation between the two factors; the relation stands positive but not too strong in nature.

Thus H2 is accepted at 0.01 level.

H3: Empathy \& Assurance of faculty impacts academic performance of students. 
TABLE VI ASSURANCE \& EMPATHY $\quad(\mathrm{N}=125)$

\begin{tabular}{|c|l|c|c|c|c|c|c|c|}
\hline \multirow{2}{*}{ Sl. No. } & \multicolumn{2}{|c|}{ Assurance \& Empathy } & \multicolumn{7}{|c|}{ <evel of Agreement >> } & \multirow{2}{*}{ Mean } & \multirow{2}{*}{ S.D. } \\
\cline { 3 - 7 } & & $\mathbf{1}$ & $\mathbf{2}$ & $\mathbf{3}$ & $\mathbf{4}$ & $\mathbf{5}$ & \\
\hline 1 & $\begin{array}{l}\text { Faculty provide counseling and mentoring to } \\
\text { students in our institution }\end{array}$ & $2(1.6)$ & $7(5.6)$ & $17(13.6)$ & $70(56.0)$ & $29(23.2)$ & 3.94 & 0.859 \\
\hline 2 & $\begin{array}{l}\text { Faculty understand the learning difficulties of } \\
\text { students in our institution }\end{array}$ & $3(2.4)$ & $11(8.8)$ & $22(17.6)$ & $60(48.0)$ & $29(23.2)$ & 3.81 & 0.973 \\
\hline 3 & $\begin{array}{l}\text { Faculty are sensitive to the incapabilities of } \\
\text { students }\end{array}$ & - & $15(12.0)$ & $39(31.2)$ & $60(48.0)$ & $11(8.8)$ & 3.54 & 0.819 \\
\hline 4 & $\begin{array}{l}\text { Faculty are trustworthy with regards to } \\
\text { confidential information about student } \\
\text { (personal background, personal issues faced } \\
\text { by him/her) }\end{array}$ & $1(0.8)$ & $8(6.4)$ & $20(16.0)$ & $67(53.6)$ & $29(23.2)$ & 3.92 & 0.848 \\
\hline 5 & $\begin{array}{l}\text { Faculty in our institution try to instil } \\
\text { confidence in student }\end{array}$ & - & $12(9.6)$ & $26(20.8)$ & $65(52.0)$ & $22(17.6)$ & 3.78 & 0.851 \\
\hline 6 & $\begin{array}{l}\text { Faculty encourage students to participate in } \\
\text { sports, games, cultural activities }\end{array}$ & $4(3.2)$ & $10(8.0)$ & $18(14.4)$ & $63(50.4)$ & $30(24.0)$ & 3.84 & 0.987 \\
\hline 7 & $\begin{array}{l}\text { Students are involved and encouraged to } \\
\text { provide useful and constructive feedback to } \\
\text { their teachers }\end{array}$ & $1(0.8)$ & $10(8.0)$ & $16(12.8)$ & $66(52.8)$ & $32(25.6)$ & 3.94 & 0.883 \\
\hline 8 & $\begin{array}{l}\text { Prompt response and action is taken to } \\
\text { resolve any student complain or grievance }\end{array}$ & $5(4.0)$ & $12(9.6)$ & $27(21.6)$ & $59(47.2)$ & $22(17.6)$ & 3.65 & 1.010 \\
\hline 9 & $\begin{array}{l}\text { Faculty provide sufficient time for } \\
\text { consultation in our institution }\end{array}$ & $4(3.2)$ & $12(9.6)$ & $25(20.0)$ & $72(57.6)$ & $12(9.6)$ & 3.61 & 0.906 \\
\hline 10 & $\begin{array}{l}\text { Students are given fair amount of freedom to } \\
\text { form associations in our institution }\end{array}$ & $4(3.2)$ & $15(12.0)$ & $27(21.6)$ & $58(46.4)$ & $21(16.8)$ & 3.62 & 1.006 \\
\hline
\end{tabular}

Note: ‘-'denotes 'no response’ Anchors: 1- Strongly disagree, 2-Disagree, 3-Neutral, 4-Agree \& 5-Strongly agree

From the above table VI, the overall mean and standard deviation of Assurance \& Empathy was observed to be 3.76 and 0.604 .

Further it was observed that, students were of opinion that faculty engages in counselling and mentoring the students and also students were encouraged to provide feedback about their teachers with a highest mean score of 3.94 followed by trustworthy of faculty with regards to confidential information about student (personal background, personal issues faced by him/her) with a mean score of 3.92 .

This suggests that, students were of opinion that Assurance \& Empathy are significant attributes that impact academic performance of students. In order to test the hypothesis Empathy \& Assurance of faculty impacts academic performance of students a correlation test was conducted and the results are as mentioned below.

TABLE VII CORRELATIONS

\begin{tabular}{|c|l|c|}
\hline \multicolumn{2}{|c|}{ Particulars } & $\begin{array}{c}\text { Academic } \\
\text { Performance }\end{array}$ \\
\hline \multirow{3}{*}{$\begin{array}{c}\text { Assurance and } \\
\text { Empathy }\end{array}$} & Pearson Correlation & $.501^{* *}$ \\
\cline { 2 - 3 } & Sig. (2-tailed) & .000 \\
\cline { 2 - 3 } & $\mathrm{N}$ & 383 \\
\hline
\end{tabular}

**. Correlation is significant at the 0.01 level (2-tailed).

From the above table VII it is evident that there is a correlation between Assurance and Empathy towards Students impacts academic performance, also it is evident that there is a correlation between the two factors whose relation stands positive but not too strong in nature. Hence H3 is accepted at 0.01 level.

\section{FINDINGS AND SUGGESTIONS}

The study focused on the academic relationship, academic resources and their impact on quality of education. The literature of the study emphasizes the importance of these factors on the quality of education. It was hypothesized that cooperation, Responsiveness, Assurance and Empathy of faculty and resources in an education setting go a long way in improving the quality of education.

The study revealed that responsiveness and cooperation is significant in student faculty relationship. It was observed that students had a stronger relationship with faculty who were consistently courteous and sensitive to their needs. It was observed that factors such as visual appeal of the facilities, access to digital platforms and innovation, industry readiness, although have a positive impact, are not very principal for learning among students.

Further it was observed that In addition to the learning environment, certain other essential factors are important 
for the students such as counseling and mentoring, co curricular and cultural activities for students, freedom of association, consultation, resolving complaints of students. These factors determine the learning abilities of students.

These findings can be useful to HEIs, in improving the teaching system and to make teachers more accountable to students and in formulating strategies to maintain or enhance their competitive benchmarks. Further studies can be carried out across HEIs to assess various tangible and intangible facilities to understand long term implications of quality improvement efforts.

The current study has focused on student faculty relationship and resources in HEIs, further researches may focus on other quality dimensions and other internal and external factors that are interlinked like other stakeholders' perspectives (such as government policies on university education, attitudes of non teaching staff, students’ attitudes regarding new course etc.).

\section{REFERENCES}

[1] Crawford, L. E. D., \& Shutler, P. (1999).Total quality management in education: Problems and issues for the classroom teacher. The Internal Journal of Educational Management, 13, 67-72. doi:10.1108/09513549910261122.

[2] Edstrom, K. (2008). Was doing course evaluations as if learning matters most. Higher Education Research and Development, 27, 95106. doi:10.1080/07294360701805234.

[3] Heck, R.H., \& Johnsrud,L.K.(2000),Administrative effectiveness in higher education: improving assessment procedures. Research in Higher Education, 41(6), pp. 663-85

[4] Magolda, Marcia., \& Astin, Alexander. (1993). What Matters in College: Four Critical Years Revisited. Educational Researcher. 22. 10.2307/1176821.

[5] Mahiah, S., Suhaimi, S., \& Ibrahim, A. (2006). Measuring the level of customer satisfaction among employees of human resource division. Advances in global Business Research, 3.

[6] Mircea, M., \& Andreescu, A. J. (2010). Agile system development for the management of service oriented organization. The 11th International Conference on Computer System and Technologies, Sofia, 17- 18 June 2010, 341-346.

[7] Navarro, M. M., Iglesias, M. P., \& Torres, P. R. (2005). A new management element of universities: Satisfaction with the courses offered. International Journal of Education Management, 19, 505 526. doi:10.1108/09513540510617454.

[8] Spooren, P., Mortelmans, D., \& Denekens, J. (2007). Student evaluation of teaching quality in higher education: Development of an instrument based on 10 Likert-scales. Assessment and Evaluation in Higher Education, 32, 667-679. doi:10.1080/02602930601117191.

[9] Wachtel, H. K. (1998). Student evaluation of college teaching effectiveness: A brief review. Assessment and Evaluation in Higher Education, 23, 191-212. doi:10.1080/0260293980230207.

[10] Wachtel, H. K. (1998). Student evaluation of college teaching effectiveness: A brief review. Assessment and Evaluation in Higher Education, 23, 191-212. doi:10.1080/0260293980230207.

[11] Zeithaml V. A., \& Binter, M. J. (2008). Service marketing integrating customer focus across the firm (4 Ed.). Boston, MA: McGraw-Hill, 108-109.

[12] Zeithaml, V. A. (1988). Consumer perceptions of price, quality and value: A means-end model and synthesis of evidence. Journal of Marketing, 52, 2-22. doi:10.2307/1251446. 